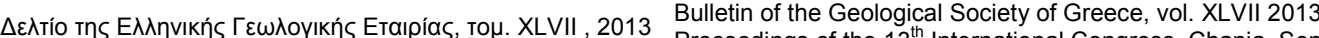
Proceedings of the $13^{\text {th }}$ International Congress, Chania, Sept.

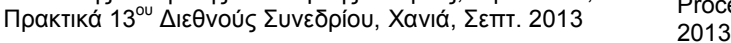

\title{
GEOMORPHOLOGICAL OUANTITATIVE ANALYSIS OF SPERCHIOS RIVER BASIN AREA (CENTRAL GREECE) UTILIZING GEOGRAPHICAL INFORMATION SYSTEMS
}

\author{
Psomiadis E. ${ }^{1}$, Migiros G. ${ }^{1}$ and Antoniou V. ${ }^{1}$ \\ ${ }^{1}$ Agricultural University of Athens, Laboratory of Mineralogy \& Geology, Iera Odos 75, 118 55, Athens, \\ mpsomiadis@gmail.com,bagm@aua.gr,vantoniou@gmail.com
}

\begin{abstract}
In the present study the analysis of the morphometric quantitative parameters of Sperchios river basin, and specifically of the 8 main sub-basins of the northern and southern part, have been made. The integrated use of a Geographic Information System (GIS) allows a thorough spatial analysis of the data derived from digital terrain spatial models that reveal the geomorphological characteristics of an area.

The thorough analysis of the results shows the significant difference of the morphological characteristics of the northern and southern part of the catchment area, due to the impact of the neotectonic activity of the area, which creates this asymmetrical topography.
\end{abstract}

Key words: Drainage network, morphometry, tectonics, spatial models.

\section{Пєрí $\eta \psi \eta$}

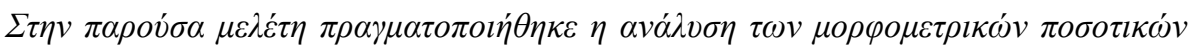

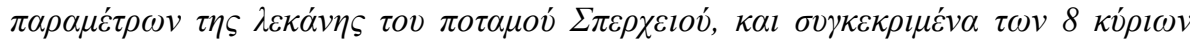

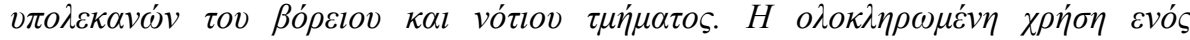

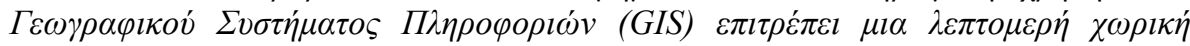

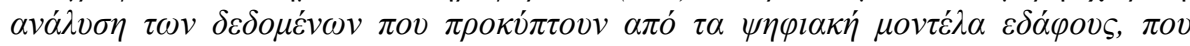

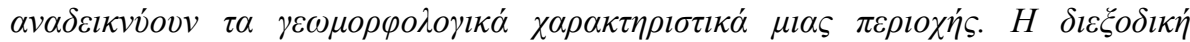

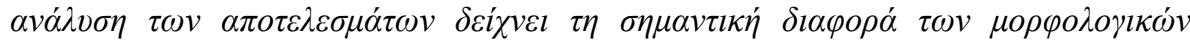

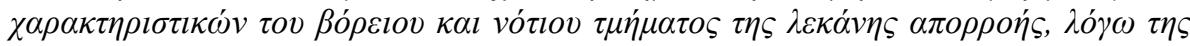

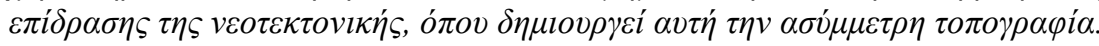

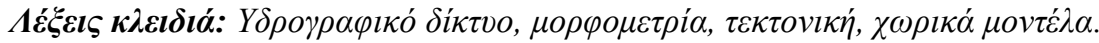

\section{Introduction}

The development of the drainage network and the morphological features within a river basin affected and dependent on many, complex and interacting parameters (Deffontaines \& Chorowicz, 1991). These factors can be classified as internal, external and complex. Essentially, the complex factors are the combination of internal and external factors. Internal factors derived from the behavior of the bedrock and controlled mainly by lithology and structure. The lithology affect through physical (permeability, increased susceptibility to erosion, hardness, etc.) and chemical properties (diagenesis, dissolution, chemistry of groundwater, etc.) of rocks. The factor of structure arises in various ways, such as the geometry, composition and thickness of rocks, and the switch in tectonic regime of rocks, which can create faults and folds (Schumm 1986). The external factors incorporate climate, vegetation and human activity.

$\underline{\text { XLVII. No } 1-325}$ 
The study area is the basin of river Sperchios in Central Greece, which lies between $38^{\circ} 44^{\prime}$ and $39^{\circ}$ $05^{\circ} \mathrm{N}$, and $21^{\circ} 50^{\circ}$ and $22^{\circ} 45^{\circ} \mathrm{N}$ (Figure 1). In the following sections the statistics and quantitatively characteristics of the 8 main sub-basins, 4 at the south part [Roustianiti (Ro), Inachou (In), Gorgopotamou (Go) and Assopou (As)] and 4 at the north part [Vitioliotis (Vi), Archanorema (Ar), Drimarorema (Dr) and Xerias-Lamias $(\mathrm{Xe})]$ of Sperchios river catchment area, are elaborated (Figure 2). Quantitative measurements of the landscape shape and drainage network characteristics allowed us to compare different landforms and to calculate the geomorphic indices that are useful to identify the landscape evolution of the basin. Geographic Information Systems (GIS) technology, focus on efficiently collecting, maintaining, manipulating and analyzing geomorphic information and a variety of spatial data (Minár et al., 2006). In particular, the core of geomophological analysis using a GIS is based on the fundamental concept of geomorphology which says that activities of geomorphological processes are explicitly represented in the shape of the georelief. This means that analysis of georelief provides correct information about the origin and development of a landscape as well as relevant data about activities of recent and present-day processes. (Psomiadis et al. 2005 ; Psomiadis, 2010).
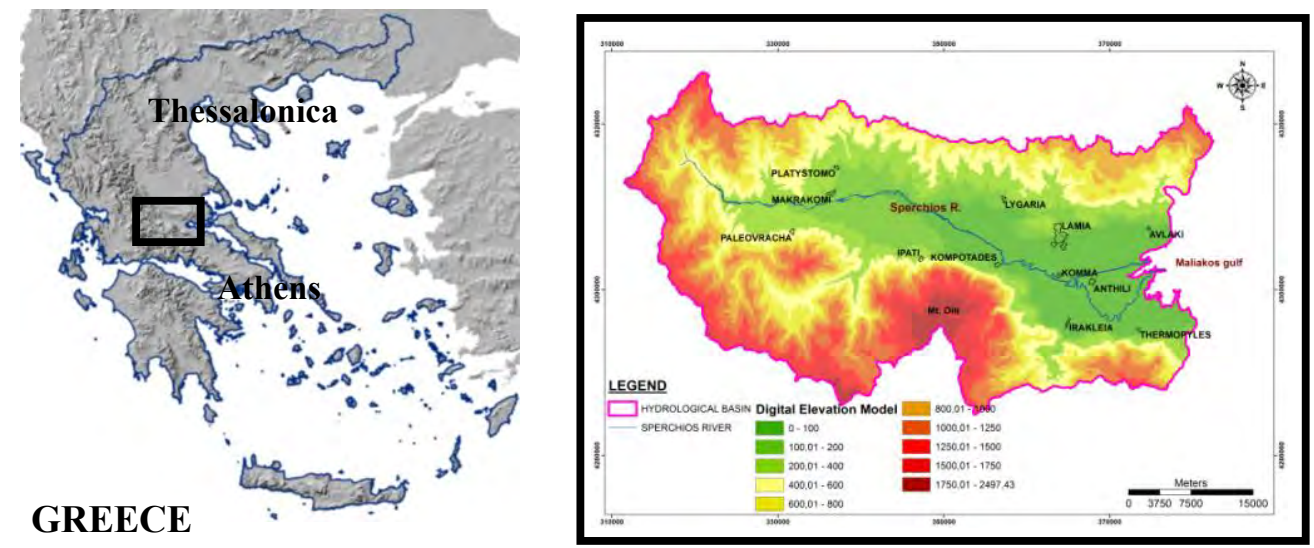

Figure 1 - Location of the study area [Digital Elevation Model (DEM) of Sperchios river basin].

\section{Data - Methodology}

For the present study, digital elevation model (DEM), derived spatial data (such as slope, aspect etc), drainage network and structural geology have been used, originated from 12 topographic and geological maps of 1:50.000 scale. Consequently, all the geospatial data were processed and analyzed through ArcGIS software suite v.9.2). The classification of the drainage network was accomplished using Strachler's classification system Strahler (1957). Using the spatial analysis of the Geographic Information System, morphometric parameters for all sub-basins and their characteristics have been calculated and analyzed. In order to investigate the relation between tectonic and drainage network development, the imprint of both high angle normal faults and small-angle reverse faults (overthrust, thrust) was made. Subsequently, a statistical analysis of the linear elements using Georient software v.8.0 and the creation of frequency (rf) and density (rd) rose diagrams, have been accomplished, both for normal and reverse faults (Figure 4) and additionally for each separately stream order of the drainage network, so as to explore the relation between drainage system and tectonic activity.

\section{Study area}

\subsection{Physical Geographical and Morphological Settings}

River Sperchios runs through a valley, which is a graben-like asymmetrical depression. Drainage network throughout the basin is dendritic and drains mountains Tymphristos, Oiti and Othrys. 


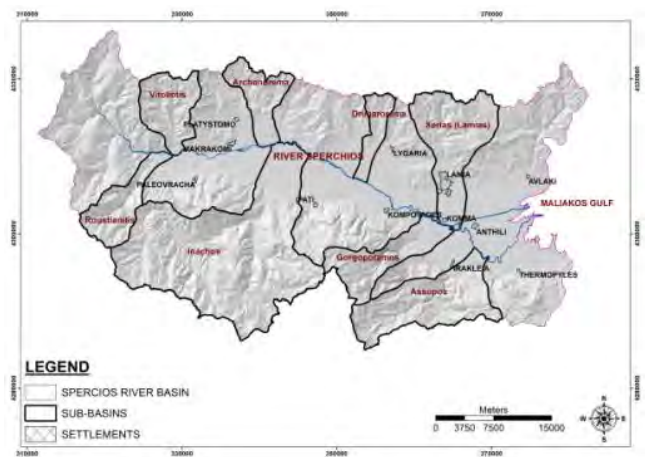

Figure 2 - The distribution of the 8 subbasins, 4 in the north and 4 in the south par t of Sperchios' river catchment area.

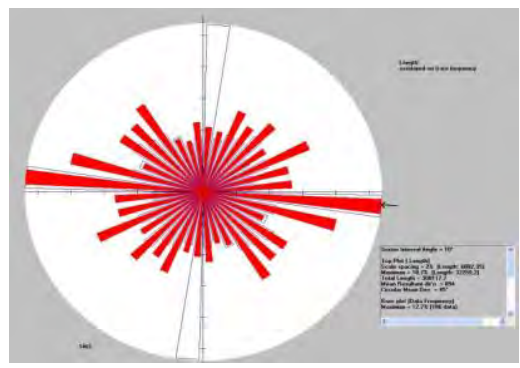

$(\alpha)$ Normal faults

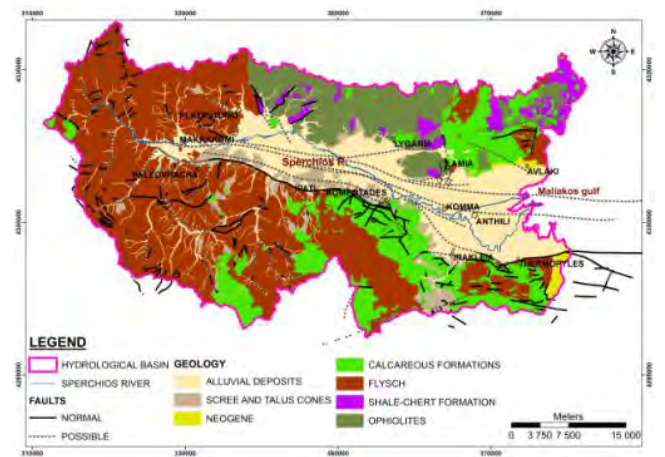

Figure 3 Simplified lithological map of Sper chios river basin, including faults and prob able faults of the area.

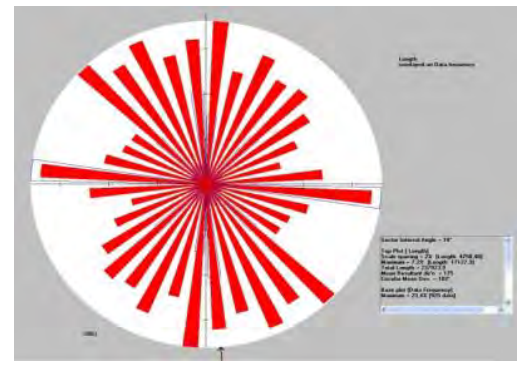

( $\beta$ ) Reverse faults

Figure 4 - Rose diagrams of frequency (rf) and density (rd) for (a) high angle normal faults $\left[\left(\mathbf{r f}=\mathbf{8 8}^{\circ} \& \mathrm{rd}=94^{\circ}(\mathrm{E}-\mathrm{W})\right]\right.$; and $(\mathrm{b})$ small-angle reverse faults (overthrust, thrust) $\left[\mathrm{rf}=174^{\circ} \&\right.$ $\mathbf{r d}=175^{\circ}$ (SSE-NNW)].

In the case of Sperchios basin, separating the basin in two parts based on river's flow direction, in north and south part, significant differences between them can be distinguished. According to the diagram of elevation and elevation areas aggregation curves (Figure 5), the southern part exhibits higher relief than the northern part, while presenting more convex curve from 200 to $1.000 \mathrm{~m}$, compared with the north in which the corresponding curve are more concave. This curvature of the curve means that from 200 to $1.000 \mathrm{~m}$, the area is increasing, as the elevation increases, while it was expected that should decrease. The cause of this anomaly is mainly due to intense tectonism and particularly at the southern part. Moreover, a large area with elevation less than $100 \mathrm{~m}$, due to the elongation of Sperchios river central bed and the spread of alluvial deposits can be depicted. Also, significant differences in terms of relief between the southern and the northern part can be distinguished, using a diagram representing the percentage of each elevation zone (Figure 6).

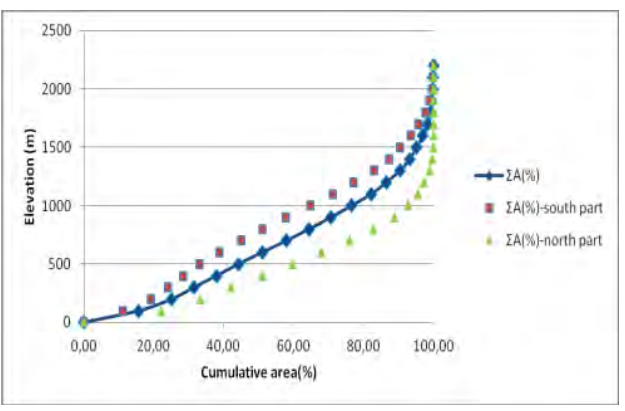

Figure 5- The relation of elevation and elev ation areas aggregation (\%).

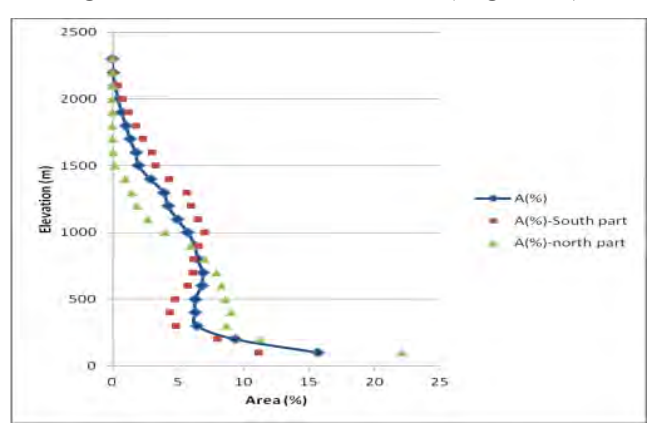

Figure 6 - The percentage of each elevation zone (\%).

XLVII. No $1-327$ 
In the northern part the percentages show highest values in elevations ranging from 400 to $700 \mathrm{~m}$, and then decrease rapidly. In contrast in the southern part the percentages normally increase normally up to approximately $1.000 \mathrm{~m}$ and then decrease smoothly at higher altitudes. The difference in elevation curve for the two parts (south and north) is due to the fact that the main river bed of Sperchios, is a graben-like asymmetrical depression with a WNW-ESE direction, parallel to the active fault of Atalanti, where the southern part is lifted and the northern is sinking (Mariolakos, 1976).

\subsection{Geological Setting}

The valley of river Sperchios is a part of a tectonic trough, which is controlled by major NW-SE and E-W trending faults parallel to Atalanti normal fault zone. More specifically, from the fault rose diagrams that have been created, it can be observed that high angle normal faults have a direction E-W, while low angle reverse faults (thrust faults) have a NW-SE direction (Figure 4). The high angle normal faults in the south and central part of the basin have a W-E and NW-SE direction, while in the north part have mainly a NE-SW direction. The fault tectonism took place at the end of the Pliocene and beginning of the Pleistocene periods. The area experienced strong earthquakes, like those which occurred in 426 B.C. and 1894 A.D. and induced big disasters in the broader study area (Mouyiaris, 1988; Pirazzoli et al. 1999).

In the drainage basin of River Sperchios, there are three distinct lithological regions according to Ferrière (1977); these are: (i) the western part that is composed of Paleocene-Eocene flysch of the East Pindus and Parnassos geotectonic zones; it is composed of alternating beds of argillitesiltstone-fine conglomerate and intercalations of shale. There is also a limited occurrence of pelagic and marly limestones of the Vardoussia zone in this area, (ii) the south-eastern portion of the basin is composed of Middle Triassic-Jurassic massive dolomites and limestones of the Pelagonian zone; Upper Cretaceous flysch consisting of coarse sandstone alternating with shale and sandy marl belonging to the zone of Beotia; and Upper Cretaceous thickl-bedded limestones and Eocene flysch, composed of sandstone, clay and marl of the Parnassos geotectonic zone, and (iii) in the north and north-eastern part, which is formed by an ophiolithic complex in a shale-chert formation composed of shales, cherts and limestones with ultra-basic and basic igneous rocksperidotite, dunite, pyroxenite, gabbro, serpentine, diabase, dolerite and metamorphosed green phyllites and schists; belonging to Maliakos (Subpelagonian) zone. In addition, Neogene and Quaternary unconsolidated deposits occupy the central and lower (elevations $<500 \mathrm{~m}$ ) part of the elongated drainage basin of the Sperchios river (Maroukian \& Lagios, 1987).

\section{Analysis and Results of the selected basins}

\subsection{Northern Part}

\subsubsection{Vitoliotis}

The Vitoliotis stream sub-basin is located in the northwestern part of Sperhios river basin and has a NW-SE direction (Figure 7a). The basin according to its morphometric characteristics (Table 1) is quite mountainous, susceptible according to its shape to flash flood phenomena. The frequency and density of the drainage network show high values, 3.73 and 9.74 respectively. These values indicate a basin which is formed mostly by impermeable rocks (flysch) and a relatively high relief favoring surface runoff and the creation of a dense drainage network. Finally, the sinuosity index is low while instead, in the main stream branch there is a tendency of elongation. The rose diagrams of faults direction indicate that stream of low Strahler's order have been affected by neotectonic activity. The streams of the 4th, 5th and 6th order streams are influenced mainly by low angle reverse faults or older faults of the area (Table 3). 


\subsubsection{Archanorema}

The Archanorema sub-basin is located in the north and central part of Sperchios river basin and has a NW-SE direction (Figure 7b). This basin according to its morphometric characteristics (Table 1) is a small basin $\left(47.4 \mathrm{~km}^{2}\right)$, semi-mountainous, with low relief. The frequency and density of the drainage network show very high values, 3.81 and 10.21 respectively. These values indicate a basin which is characterized by the presence of semi-permeable and impermeable formations (flysch and ophiolites) leading to a dense drainage network. Finally, the sinuosity index is very low indicating the absence of meander. The rose diagrams of faults direction indicate that the streams of $1^{\text {st }}, 2^{\text {nd }}$ and of $4^{\text {th }}$ up to $6^{\text {th }}$ order present a SE-NW direction, following the low angle reverse faults. Oppositely, the $3^{\text {rd }}$ order streams, present a SW-NE direction, following the high angle normal faults, affected by neotectonic activity (Table 3)

\subsubsection{Drimarorema}

The Drimarorema sub-basin is situated in the north-central part of Sperchios river basin and has a NE-SW direction (Figure 7c). This basin according to its morphometric characteristics (Table 1) is a small basin $\left(26.6 \mathrm{~km}^{2}\right)$, with a very low total relief and mean slope value. The elongation ratio shows a tendency of elongation. The frequency and density of the drainage network represent high values, 3.7 and 8.75 respectively. These values indicate a basin which is characterized by the presence of semi-permeable formations (ophiolites) leading to the creation of a dense drainage network. Finally, the sinuosity index is very low indicating the absence of meander. The rose diagrams of faults direction indicate that the streams of $3^{\text {rd }}$ up to $5^{\text {th }}$ order (main branch) present a SE-NW direction, following the low angle reverse faults. Oppositely, the $1^{\text {st }}$ and $2^{\text {nd }}$ order streams, present a W-E and NE-SW direction, following the high angle normal faults, affected by neotectonic activity of the area (Table 3 ).

\subsubsection{Xerias (Lamias)}

The Xerias (Lamias) sub-basin is situated in the northeastern part of Sperchios river basin at the west part of Othrys Mountain and has a N-NW to S-SE direction (Figure 7d). This basin according to its morphometric characteristics (Table 1) is a medium to large basin $\left(109.7 \mathrm{~km}^{2}\right)$, the largest of the northern part. It has a high total relief and the elongation ratio shows a tendency of elongation. The frequency and density of the drainage network represent low values, 2.08 and 4.12 respectively. These values indicate a basin which is characterized by the presence of permeable formations (calcareous) leading to the creation of a sparse drainage network. The low values of frequency, is also due to the low relief and slopes of the basin. Finally, the sinuosity index is low indicating the absence of meander. The rose diagrams of faults direction indicate that the streams of $1^{\text {st }}$ up to $4^{\text {th }}$ order present a E-W direction, following the high angle normal faults affected by neotectonic activity of the area, while the main branch of the stream $\left(5^{\text {th }}\right.$ order $)$ present a NE-SW direction following the low angle reverse faults or older faults of the area (Table 3)

\subsection{Southern Part}

\subsubsection{Roustianitis}

The Roustianitis sub-basin is situated in the southwestern part of Sperchios river basin and has a SW to NE direction (Figure 8a). The $85 \%$ of this sub-basin lies in elevations higher than $600 \mathrm{~m}$, while the $75 \%$ belongs to the very mountainous area. This basin according to its characteristics (Table 2) is a medium size basin $\left(53.11 \mathrm{~km}^{2}\right)$. It has high values of mean elevation, total relief and steep slopes. Similar high values of relief ratio and slope index is observed. The length-width ratio appears high, presenting an elongated basin, affected probably also by the neotectonic activity of the area. Regarding the frequency and density of the drainage network, this present low values, 2.33 and 3.86 respectively. Oddly, these values are mismatched with the fact that the basin is formed mainly with flysch which gives usually a dense drainage network. Instead of that the drainage network is sparse, due apparently to the presence of the very high relief and the steep 
slopes of the basin. The rose diagrams of faults direction indicate that the streams of $1^{\text {st }}$ and $2^{\text {nd }}$ order present a SE-NW and E-W direction, respectively, following the high angle normal faults. On the contrary, the branches of $3^{\text {rd }}, 4^{\text {th }}$ and $5^{\text {th }}$ order present a NE-SW direction following the structure of low angle reverse faults (upthrusts, overthrusts) (Table 3).

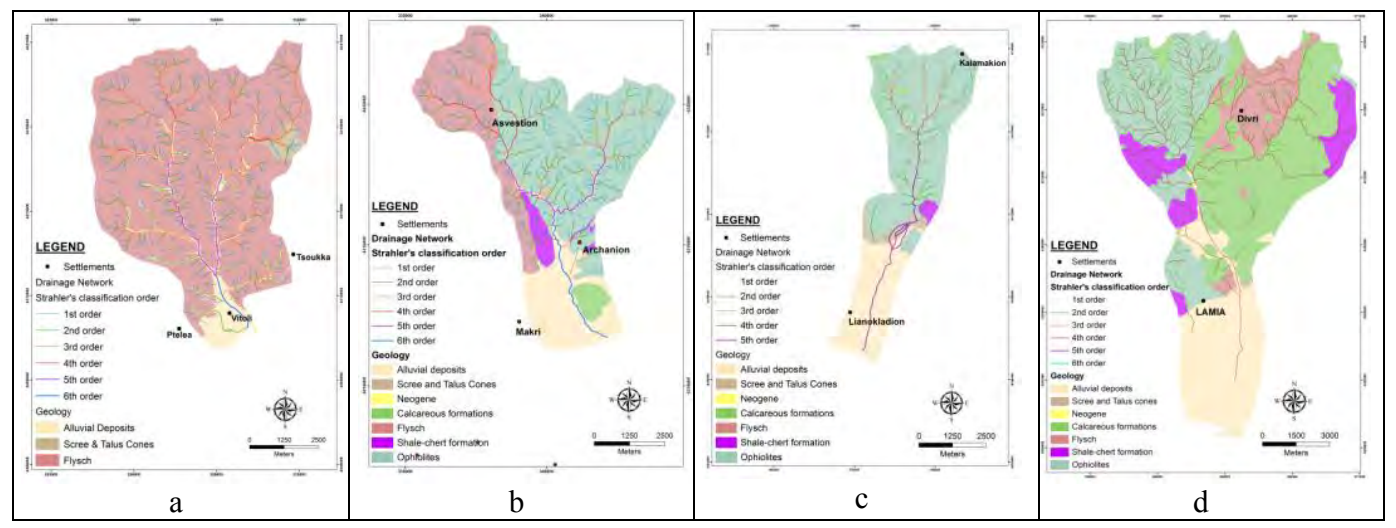

Figure 7 - The 4 sub-basins of the northern part (a)Vitoliotis, (b)Archanorema, (c) Drimarorema and (d) Xerias (Lamias). It is presented the geology and the drainage network.

Table 1 - The morphometric characteristics of the northern part sub-basins.

\begin{tabular}{|l|l|r|r|r|r|}
\hline \multicolumn{1}{|c|}{ Parameter } & Symbol/ Equation & \multicolumn{1}{c|}{$\begin{array}{c}\text { Vito- } \\
\text { liotis }\end{array}$} & $\begin{array}{c}\text { Archano- } \\
\text { rema }\end{array}$ & $\begin{array}{c}\text { Drima- } \\
\text { rorema }\end{array}$ & $\begin{array}{c}\text { Xerias } \\
\text { (Lamias) }\end{array}$ \\
\hline Area $\left(\mathrm{km}^{2}\right)$ & $\mathrm{A})$ & 58.85 & 47.40 & 26.62 & 109.74 \\
\hline Basin Length $(\mathrm{km})$ & $(\mathrm{Lb})$ & 10.47 & 12.22 & 11.84 & 17.63 \\
\hline Basin width $(\mathrm{km})$ & $(\mathrm{Br}=\mathrm{A} / \mathrm{Lb})$ & 5.62 & 3.88 & 2.18 & 6.22 \\
\hline Perimeter $(\mathrm{km})$ & $(\mathrm{P})$ & 36.28 & 38.54 & 30.84 & 57.63 \\
\hline Maximum Elevation hmax $(\mathrm{m})$ & - & $1,281.31$ & 826.45 & 820.5 & $1,085.51$ \\
\hline Minimum Elevation - hmin $(\mathrm{m})$ & - & 215.00 & 100.00 & 30.8 & 12.00 \\
\hline Total relief $(\mathrm{m})$ & $\mathrm{H}=\mathrm{hmax}-\mathrm{hmin}$ & $1,066.31$ & 726.45 & 789.70 & $1,073.51$ \\
\hline Median elevation $-\mathrm{hmedian}(\mathrm{m})$ & - & 670.00 & 420.00 & 285.00 & 593.14 \\
\hline Mean Elevation - hmean $(\mathrm{m})$ & - & 747.41 & 452.64 & 456.14 & 540.00 \\
\hline Basin mean slope $(\%)$ & $\mathrm{BS}=\mathrm{\Sigma Li} \mathrm{d} / \mathrm{A}$ & 44.00 & 32.00 & 28.00 & 30.00 \\
\hline Relief ratio $(\mathrm{RH})(\mathrm{m} / \mathrm{km})$ & $\mathrm{RH}=\mathrm{H} /(\mathrm{Lb})$ & 101.84 & 59.45 & 66.70 & 60.89 \\
\hline Length-Width index $(\mathrm{S})$ & $\mathrm{S}=(\mathrm{Lb}) /(\mathrm{Br})$ & 1.86 & 3.15 & 5.43 & 2.83 \\
\hline Basin shape index & $\mathrm{Rf}=\mathrm{A} / \mathrm{Lb}{ }^{2}$ & 0.54 & 0.32 & 0.19 & 0.35 \\
\hline Basin circularity ratio & $\mathrm{Rc}=4 \pi \mathrm{A} / \mathrm{P}^{2}$ & 0.56 & 0.40 & 0.35 & 0.42 \\
\hline Basin elongation ratio & $\mathrm{Re}=1.129(\mathrm{~A})^{0,5} / \mathrm{Lb}$ & 1.54 & 0.64 & 0.49 & 0.67 \\
\hline Dr. network density index & $\mathrm{Co}=0.282 \mathrm{P} /(\mathrm{A})^{0,5}$ & 1.33 & 1.58 & 1.69 & 1.55 \\
\hline Number of streams & $(\mathrm{Nu})$ & 573.00 & 484.00 & 233.00 & 452.00 \\
\hline Total stream length $(\mathrm{km})$ & $(\mathrm{L})$ & 219.77 & 180.78 & 98.48 & 228.48 \\
\hline Main stream length $(\mathrm{km})$ & $\mathrm{Lm}$ & 11.56 & 14.46 & 12.49 & 19.30 \\
\hline Density $\left(\mathrm{km} / \mathrm{km}{ }^{2}\right)$ & $\mathrm{D}=(\mathrm{L}) /(\mathrm{A})$ & 3.73 & 3.81 & 3.70 & 2.08 \\
\hline Frequency $\left(1 / \mathrm{km}{ }^{2}\right)$ & $\mathrm{F}=(\mathrm{N}) /(\mathrm{A})$ & 9.74 & 10.21 & 8.75 & 4.12 \\
\hline Sinuosity index & $\mathrm{C}=\mathrm{Lm} / \mathrm{Lb}$ & 1.10 & 1.18 & 1.06 & 1.10 \\
\hline Slope index $(\mathrm{m} / \mathrm{km})$ & $\mathrm{Sr}=\mathrm{H} / \mathrm{Lm}$ & 52.24 & 50.23 & 63.23 & 55.62 \\
\hline
\end{tabular}




\subsubsection{Inachos}

The Inachos sub-basin is situated in the southwestern part of Sperchios river basin, covering a very big part of it and has a SW to NE direction (Figure $8 \mathrm{~b}$ ). The main branch of the river, according to the Strahler's classification, is of the 7th order, which intersects with Sperchios, giving the final 8th order that flows into Maliakos gulf. The $89 \%$ of this basin lies in elevations higher than $600 \mathrm{~m}$, while the $78.5 \%$ belongs to mountainous area. This basin according to its morphometric characteristics (Table 2) is the biggest sub-basin of Sperchios $\left(341.86 \mathrm{~km}^{2}\right)$. It has a very high value of mean elevation and total relief. As far as it concerns the frequency and density of the drainage network present very high values, 3.49 and 8.45 respectively. These values are due to the domination of flysch formation in the basin. The high value of frequency indicates also that the basin is influenced by the tectonic activity of local fault zones. The sinuosity is relatively low indicating the absence of meander. The rose diagrams of faults direction indicate that the streams of $1^{\text {st }}$ order show an E-W following the high angle normal faults. The branches of $3^{\text {rd }}$ and $4^{\text {th }}$ order present a S/SE-N/NW direction following the structure of the low angle reverse faults. The branches of $2^{\text {nd }}, 3^{\text {rd }}, 6^{\text {th }}$ and $7^{\text {th }}$ order present a NE-SW direction, following the normal faults, but they are mainly affected from the existing geological structure (Table 3 ).

\subsubsection{Gorgopotamos}

The Gorgopotamos sub-basin is situated in the southeastern part of Sperchios river basin, originates from the eastern part of mountain Oiti and has a W-SW to E-NE direction (Figure 8c). The $76.3 \%$ of this basin lies in elevations higher than $600 \mathrm{~m}$, while the $74.6 \%$ belongs to the mountainous area. A special feature of this basin is the well known from historical events canyon of Gorgopotamos. The creation of the canyon is due to the steep slopes of the basin and the transition of the geological formations from flysch to carbonate rocks. The presence of the impermeable flysch formation at the upper part of the basin causes a very high surface runoff of rainfall water, while the steep slopes of the basin lead to a very fast water flow. At the transition point that embarks on the existence of the carbonate rocks, which are much more erodible than the flysch formation, the creation of the canyon is started up. The whole process is further enhanced by the Sperchios southern part lifting processes, which along with the existing steep slopes favor the retrogressive erosion creation. This basin according to its morphometric characteristics (Table 2 ), is a medium size basin $\left(67.62 \mathrm{~km}^{2}\right)$ and it has high total relief and steep slopes. The elongation ratio is rather high, presenting an elongated basin, affected probably and by the neotectonic activity of the area. As regards the frequency and density of the drainage network they have medium to high values, 2.75 and 5.87 respectively. These values indicate a basin which is characterized by the presence of permeable calcareous formations, leading to the creation of a sparse drainage network, except from the north part of the basin that flysch formation is appeared. Finally, the sinuosity index is low indicating the absence of meander. The rose diagrams of faults direction indicate that the streams of $1^{\text {st }}$ up to $4^{\text {th }}$ order present mainly a E-W direction, following the high angle normal faults, as well as the main branch of the river $\left(5^{\text {th }}\right.$ order $)$ presenting a NESW direction and seems to be affected either from high angle normal faults and other older faults of the area (Table 3).

\subsubsection{Assopos}

The Assopos sub-basin is situated in the southeastern part of Sperchios river basin, originates from southeastern part of mountain Oiti and has a W-SW to E-NE direction (Figure 8d). In nowadays, subsequently to the infrastructure and drainage constructions that occurred the last decades in the coastal area of Sperchios basin, Assopos is the only river that supply at the downstream part of Sperchios river. The $73.6 \%$ of this basin lies in elevations higher than $600 \mathrm{~m}$, while the $58.8 \%$ belongs to the very mountainous area. The values of the elongation ratio and the length-width index, present an elongated basin, affected by the neotectonic activity of the area. As far as it concerns, the frequency and density of the drainage network have medium values, 2.35 and 4.64 respectively. These values indicate a basin which is characterized by the presence of permeable

$\underline{\text { XLVII, No } 1 \text { - } 331}$ 
calcareous formations that lead to the creation of a sparse drainage network. The high value of the frequency indicates also the basin is influenced by the tectonic activity of the local fault zones. The sinuosity is relatively low and indicates the absence of meander. The rose diagrams of faults direction indicate that the streams of $1^{\text {st }}$ up to $4^{\text {th }}$ order exhibit an E-W and SE-NW direction, following the high angle normal faults, as well as the main branch of the river $\left(5^{\text {th }}\right.$ order) which presents a NE-SW direction and seems to be affected either from high angle normal faults and other older faults of the area (Table 3).

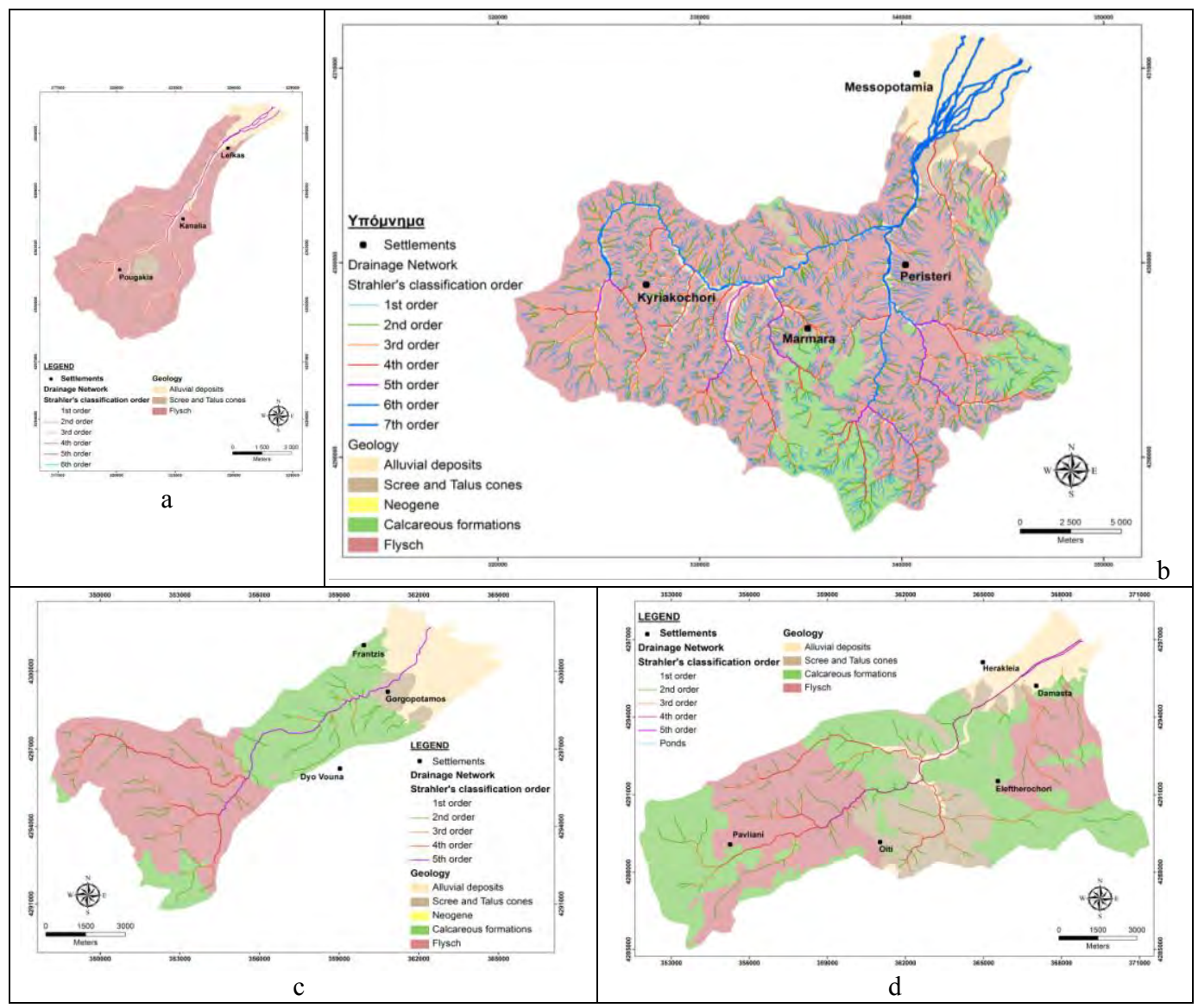

Figure 8 - The 4 sub-basins of the southern part (a) Roustianitis (b)Inachos, (c)

Gorgopotamos and (d)Assopos. It is demonstrated the geology and the drainage network.

Table 2 - The morphometric characteristics of the southern part sub-basins.

\begin{tabular}{|l|l|r|r|r|r|}
\hline \multicolumn{1}{|c|}{ Parameter } & \multicolumn{1}{|c|}{$\begin{array}{c}\text { Sym- } \\
\text { bol/Equation }\end{array}$} & \multicolumn{1}{c|}{$\begin{array}{c}\text { Roustiani- } \\
\text { tis }\end{array}$} & \multicolumn{1}{c|}{$\begin{array}{c}\text { Ina- } \\
\text { chos }\end{array}$} & $\begin{array}{c}\text { Gor- } \\
\text { gopota- } \\
\text { mos }\end{array}$ & $\begin{array}{c}\text { As- } \\
\text { sopos }\end{array}$ \\
\hline Area $\left(\mathrm{km}^{2}\right)$ & $(\mathrm{A})$ & 53.11 & 341.86 & 67.62 & 112.97 \\
\hline Basin Length $(\mathrm{km})$ & $(\mathrm{Lb})$ & 14.61 & 29.21 & 15.06 & 19.45 \\
\hline Basin width $(\mathrm{km})$ & $(\mathrm{Br}=\mathrm{A} / \mathrm{Lb})$ & 3.64 & 11.70 & 4.50 & 5.81 \\
\hline Perimeter $(\mathrm{km})$ & $(\mathrm{P})$ & 39.67 & 104.58 & 52.90 & 58.95 \\
\hline Maximum Elevation hmax $(\mathrm{m})$ & - & $1,724.61$ & $2,293.64$ & $2,150.61$ & $1,804.25$ \\
\hline Minimum Elevation hmin $(\mathrm{m})$ & - & 240.50 & 90 & 14.00 & 8.00 \\
\hline Total relief $(\mathrm{m})$ & $\mathrm{H}=$ hmax-hmin & $1,484.11$ & $2,203.64$ & $2,136.61$ & $1,796.25$ \\
\hline Median elevation - hmedian $(\mathrm{m})$ & - & 940.00 & 962.00 & 1.320 .00 & 680.00 \\
\hline
\end{tabular}

XLVII. No $1-332$ 


\begin{tabular}{|l|l|r|r|r|r|}
\hline Mean Elevation - $\mathrm{hmean}(\mathrm{m})$ & - & 998.70 & $1,155.36$ & 1.089 .70 & 946.94 \\
\hline Basin mean slope $(\%)$ & $\mathrm{BS}=\Sigma \mathrm{Li} \mathrm{d} / \mathrm{A}$ & 0.40 & 0.42 & 0.41 & 0.46 \\
\hline Relief ratio $(\mathrm{RH})(\mathrm{m} / \mathrm{km})$ & $\mathrm{RH}=\mathrm{H} /(\mathrm{Lb})$ & 101.58 & 75.44 & 141.87 & 92.35 \\
\hline Length-Width index $(\mathrm{S})$ & $\mathrm{S}=(\mathrm{Lb}) /(\mathrm{Br})$ & 4.01 & 2.50 & 3.35 & 3.35 \\
\hline Basin shape index & $\mathrm{Rf}=\mathrm{A} / \mathrm{Lb}^{2}$ & 0.25 & 0.40 & 0.30 & 0.30 \\
\hline Basin circularity ratio & $\mathrm{Rc}=4 \pi \mathrm{A} / \mathrm{P}^{2}$ & 0.42 & 0.39 & 0.30 & 0.41 \\
\hline Basin elongation ratio & $\mathrm{Re}=1.129(\mathrm{~A})^{0,5} /$ & 0.21 & 0.72 & 0.62 & 0.62 \\
& $\mathrm{Lb}$ & & & & \\
\hline Dr. network density index & $\mathrm{Co}=0.282 \mathrm{P} /(\mathrm{A})^{0,5}$ & 1.53 & 1.60 & 1.82 & 1.56 \\
\hline Number of streams & $(\mathrm{Nu})$ & 205.00 & $2,887.00$ & 397.00 & 524.00 \\
\hline Total stream length $(\mathrm{km})$ & $(\mathrm{L})$ & 123.64 & $1,193.69$ & 185.74 & 259.91 \\
\hline Main stream length $(\mathrm{km})$ & $\mathrm{Lm}$ & 15.50 & 30.40 & 15.88 & 21.60 \\
\hline Density $(\mathrm{km} / \mathrm{km} 2)$ & $\mathrm{D}=(\mathrm{L}) /(\mathrm{A})$ & 2.33 & 3.49 & 2.75 & 2.30 \\
\hline Frequency $(1 / \mathrm{km} 2)$ & $\mathrm{F}=(\mathrm{N}) /(\mathrm{A})$ & 3.86 & 8.45 & 5.87 & 4.64 \\
\hline Sinuosity index & $\mathrm{C}=\mathrm{Lm} / \mathrm{Lb}$ & 1.06 & 1.04 & 1.05 & 1.11 \\
\hline Slope index $(\mathrm{m} / \mathrm{km})$ & $\mathrm{Sr}=\mathrm{H} / \mathrm{Lm}$ & 95.75 & 72.49 & 134.54 & 83.16 \\
\hline
\end{tabular}

Table 3 - Drainage network orientation of frequency (rf) and density (rd) according to the relevant rose diagrams

\begin{tabular}{|c|c|c|c|c|c|c|c|c|c|}
\hline \multirow{2}{*}{\multicolumn{2}{|c|}{ Parameter }} & $\mathbf{V i}$ & Ar & Dr & $\mathbf{X e}$ & Ro & In & Go & As \\
\hline & & \multicolumn{4}{|c|}{ North part } & \multicolumn{4}{|c|}{ South part } \\
\hline \multirow{8}{*}{$\begin{array}{l}\text { Fre- } \\
\text { quenc } \\
\text { y and } \\
\text { Densi- } \\
\text { ty } \\
\text { drain- } \\
\text { age } \\
\text { orien- } \\
\text { tation }\end{array}$} & $\begin{array}{l}\text { Or- } \\
\text { der }\end{array}$ & rf, rd & rf, rd & rf, rd & rf, rd & rf, rd & rf, rd & rf, rd & rf, rd \\
\hline & 1 & E-W & $\begin{array}{l}\text { S/SE- } \\
\text { N/NW }\end{array}$ & E-W & E-W & SE-NW & E-W & E-W & $\begin{array}{l}\text { SE- } \\
\text { NW }\end{array}$ \\
\hline & 2 & E-W & $\begin{array}{l}\text { S/SE- } \\
\text { N/NW }\end{array}$ & $\begin{array}{c}\text { W/NW- } \\
\text { E/SE }\end{array}$ & E-W & E-W & $\begin{array}{l}\text { N/NE- } \\
\text { S/SW }\end{array}$ & E-W & $\begin{array}{l}\text { SE- } \\
\text { NW }\end{array}$ \\
\hline & 3 & E-W & $\begin{array}{l}\text { E/NE- } \\
\text { W/SW }\end{array}$ & $\begin{array}{l}\text { N/NE- } \\
\text { S/SW }\end{array}$ & $\begin{array}{c}\text { W/N } \\
W- \\
\text { E/SE }\end{array}$ & $\begin{array}{l}\text { N/NE- } \\
\text { S/SW }\end{array}$ & $\begin{array}{l}\text { N/NE- } \\
\text { S/SW }\end{array}$ & $\begin{array}{l}\text { W/NW } \\
-\mathrm{E} / \mathrm{SE}\end{array}$ & E-W \\
\hline & 4 & $\begin{array}{c}\mathrm{N} / \mathrm{NE} \\
- \\
\mathrm{S} / \mathrm{SW} \\
\end{array}$ & SE-NW & $\begin{array}{l}\text { N/NE- } \\
\text { S/SW }\end{array}$ & $\begin{array}{c}\text { W/N } \\
W- \\
\text { E/SE }\end{array}$ & $\begin{array}{l}\text { W/SW- } \\
\text { E/NE }\end{array}$ & $\begin{array}{l}\text { S/SE- } \\
\text { N/NW }\end{array}$ & E-W & E-W \\
\hline & 5 & $\begin{array}{c}\text { S/SE- } \\
\mathrm{N} / \mathrm{N} \\
\mathrm{W}\end{array}$ & $\begin{array}{l}\text { N/NE- } \\
\text { S/SW }\end{array}$ & $\begin{array}{l}\text { N/NE- } \\
\text { S/SW }\end{array}$ & $\begin{array}{l}\text { NE- } \\
\text { SW }\end{array}$ & NE-SW & $\begin{array}{l}\text { S/SE- } \\
\text { N/NW }\end{array}$ & NE-SW & $\begin{array}{l}\text { NE- } \\
\text { SW }\end{array}$ \\
\hline & 6 & $\begin{array}{l}\text { S/SE- } \\
\text { N/NW }\end{array}$ & SE-NW & & - & - & $\begin{array}{l}\text { N/NE- } \\
\text { S/SW }\end{array}$ & - & - \\
\hline & 7 & - & - & - & - & - & $\begin{array}{l}\text { N/NE- } \\
\text { S/SW }\end{array}$ & - & - \\
\hline
\end{tabular}

\section{Conclusions}

Based on a thorough geospatial analysis of the features in the 8 main sub-basins of Sperchios catchment area, a wealth of useful information on the morphology was extracted. In particular it is clear that the sub-basins at the southern part are clearly longer and have relatively smaller width according to their size, while the basins at the northern part, present higher circularity. Additionally, the relief at the south is steeper, with steeper slopes, higher total relief and mean elevation. These characteristics are due probably to the influence of neotectonic activity of the area and the effects of EW faults, which conduce to the lift process of the southern part and the sinking and widening process of the northern part. The drainage network follows these movements and as 
a consequence the branches of the streams in the south are longer and sparse, while in the north are shorter, and dense. Moreover, at the evolution processes of the drainage network, the geological background of the area constitutes a fundamental parameter. In Sperchios basin, the western and southwestern part of the basin are dominated by impermeable rocks (flysch), which form a dense drainage network, while in the south-southeastern part of the basin dominated the permeable calcareous rocks, which form a sparse network.

The frequency and density of the drainage network have mostly moderate to high values, mainly due to geological bedrock and the recent ongoing neotectonic activity of the area. Moreover, the highest values of density are noted at the impermeable and semi-permeable geological formations. According to the frequency and density rose diagrams of the drainage network, can be detected that in the sub-basins of the southern part the main orientation is E-W and less E/SE-W/NW and E/NE-W/SW following the high angle normal faults, which affect and form the whole basin of Sperchios. A small exception can be noticed in the sub-basin of Inachos river, where is affected also from older local faults and shows a NE rotation around of a NE-SW axis. This phenomenon influences the drainage network development. Oppositely, at the northern part the drainage network presents a S/SE-N/NW and less NE-SW orientation, following the low angle reverse faults (upthrust, overthrusts). An exception of that is occurred in the western part, which is affected mainly by the normal faults or from older local faults with an E-W orientation.

\section{Acknowledgments}

During preparation of the manuscript the State Scholarships Foundation of Greece supported one of the authors (E. Psomiadis).

\section{References}

Deffontaines B., Chorowicz J., 1991. Principles of drainage basin analysis from multisource data: Application to the structural analysis ofthe Zaire basin. In: J. Fourniguet \& G. Pierre (Eds), Neotectonics. Tectonophysics, 194, pp. 237-263.

Mariolakos H., 1976. Thoughts and views on certain issues of Geology and Tectonics of the Peloponnese. Ann.Geol.Pays Hellen.,27, 215-313.

Maroukian H., Lagios E., 1987. Neotectonic movements in the Sperkhios River basin, Central Greece. Z.Geomorph.N.F., Suppl.-Bd. 63, 133-140.

Mentlík P., Jedlička K., Minár J., Barka I., 2006. Geomorphological information system: physical model and options of geomorphological analysis. Geografie, Sborník České Geografické Společnosti, p. 15-31.

Mouyiaris N.K., 1988. Destructive historical earthquakes in N. Euboicos and Maliacos GulfsTheir significance to the evolution of the area. Proceedings of the Engineering geology of ancient works, monuments and historical sites-Preservation and Protection, Vol. 3, pp. 1249-1256, Balkema, Rotterdam.

Pirazzoli P.A., Stiros S.C., Arnold M., Laborel J., Laborel-Deguen F., 1999. Late Holocene coeseismic vertical displacements and tsunami deposits near Kynos, gulf of Euboea, central Greece. Phys. Chem. Earth (A), Vol.24, No 4, 361-367.

Psomiadis E., Parcharidis I., Stamatis G., Foumelis M., 2005. Remotely sensing data and thematic mapping for sustainable developing in Sperchios river basin (Central Greece). Proc. of SPIE 5983, Remote Sensing for Environmental Monitoring, GIS Apps and Geology.

Psomiadis E., 2010. Geomorphologic and environmental changes research in the Sperchios river basin utilizing new technologies (Remote Sensing \& GIS). Doctorate Thesis elaborated at the Agricultural University of Athens, Lab. of Mineralogy \& Geology, p. 394.

Schumm S.A., 1986. Alluvial river response to active tectonics. In: R.E. Wallace (Eds), Active Tectonics. Natl. Acad. Press, Washington, D.C., pp. 80-94.

Strahler N.A., 1957. Quantitative analysis of watershed geomorphology. Amer. Geophys. Union, Trans., 38 (6), 1117-1142.

XLVII. No $1-334$ 